\title{
Sustainability of Wonosobo's Coffee Agriculture and Industry from Community-Based Conservation Perspective
}

\author{
Pramudya Lazuardi ${ }^{*}$, Ariya Jati ${ }^{1}$, and Rifka Pratama ${ }^{1}$ \\ ${ }^{1}$ English Department, Faculty of Humanities, Diponegoro University, Indonesia
}

\begin{abstract}
Despite being primarily a rice-agriculture nation, Indonesia is one of the world's top coffee consumers. In Indonesia, coffee consumption reached $1.13 \mathrm{~kg}$ per year. Wonosobo Regency has been one of the coffeeproducing areas in the country for years. Wonosobo's coffee production is sustainable due to policies and needs that emphasize community-based conservation. In terms of community conservation, this study looks at the sustainability of agriculture and the coffee industry in Wonosobo. The research data was collected from field observations, interviews with relevant sources, and literature review studies in conjunction with the discussion. This study focuses on social effects using qualitative methods. Per the findings of this report, Wonosobo has a concept of sustainable agriculture and the coffee industry built on community-based conservation. There is a principle of synergy between farmer groups, coffee processors, government, and other related roles that focus on social, environmental, economic, and cultural values to support the realization of sustainable agriculture and coffee industry in Wonosobo, even in the pandemic situation.
\end{abstract}

\section{Introduction}

Community and environment are intricately interwoven and cannot be overlooked. People rely on nature to survive. Furthermore, their influence is essential to the world's sustaining existence today. This is a life cycle occurring in Wonosobo's agricultural and coffee industry.

Wonosobo is a regency in Central Java. It has $948.68 \mathrm{~km}^{2}$ area and is located between $7^{0} 11^{\prime}$ and $7^{0} 36^{\prime}$ south latitude, $109^{\circ} 43^{\prime}$ and $110^{\circ} 04^{\prime}$ east longitude. Wonosobo is also a mountainous area, with elevations ranging from 275 to 2250 meters above sea level and 207 days of rainfall in 2020 [1]. Despite the high risk of landslides, Wonosobo has successfully utilized agricultural potential as a source of income for most of the population, especially rice, corn, tubers, and beans.

Farmers in Wonosobo who started modernizing took advantage of the Indonesian coffee consumption trend, which continued to expand from time to time. In Indonesia, coffee intake climbed 44\% between 2008 and 2019, reaching $1.13 \mathrm{~kg}$ per year. Meanwhile, Indonesia's consumption rate was the highest among Asia and Oceania's developing nations in September 2019, hitting 13.5\% [2]. Some farmers in Wonosobo have grown coffee, from the

\footnotetext{
* Corresponding author: pramudyalaz@gmail.com
} 
most traditional approach to the advanced technique. In 2019, the robust coffee plantation area was 1,604.35 hectares and for arabica coffee is 1,498.58 ha. Meanwhile, robust coffee production reached 494.78 tons, while arabica coffee reached 178.09 tons [3].

This study aims to determine what factors make Wonosobo's agricultural and coffee business sustainable from a community-based conservation approach. This research also looks at the interaction between Wonosobo's coffee industry and the environment and the roles of the many elements involved.

\section{Literature Review}

Conservation, in general, is a practice aimed at protecting living natural resources and preventing extinction, harm, or degradation. It refers to managing, protecting, and restoring natural resources and the ecosystem [4]. Conservation, according to these two meanings, refers to the interaction between humans and the environment.

Humans already developed conservation awareness in prehistoric times, however traditionally. One way is through switching hunting and gathering lifestyle to farming and cattle-raising. Furthermore, the conservation concept is employed to improve the quality of human life while protecting, maintaining, and utilizing existing natural resources. From then, conservation moved to a philosophy of community-based conservation (CBC).

Community-based conservation is a conservation concept that employs community outreach as the major actor in integrated conservation and sustainability activities to accomplish both social-economy and conservation objectives[5]. This research includes the following subjects: (1) The fundamental socio-cultural, economic, and ecological values of the agricultural and coffee industries influencing CBC growth and development; (2) the objective of applying the $\mathrm{CBC}$; (3) the role of each community element involved; and (4) the environmental, agricultural and coffee industry outcomes of Wonosobo.

\section{Methodology of The Study}

This field research focuses on the Kalikajar sub-district, Wonosobo district, Central Java Province, Indonesia. To obtain analytical data, the writer employs interviews and field observation. This study recruited six informants from each field study region with different backgrounds as research samples. Key informants from various farming and coffee sectors were questioned. Field observations were performed to examine conditions in the field firsthand. Meanwhile, the writer additionally performs a literature study to support researchrelated references.

After that, the qualitative data results are objectively summarized, processed, and synthesized. The results would then be explained in a descriptive manner.

\section{Findings}

The author employs the following map as a conceptual framework when undertaking the research. The arrows show the scheme of cooperation between each element. Meanwhile, the writer employs further explanations below the figure. 


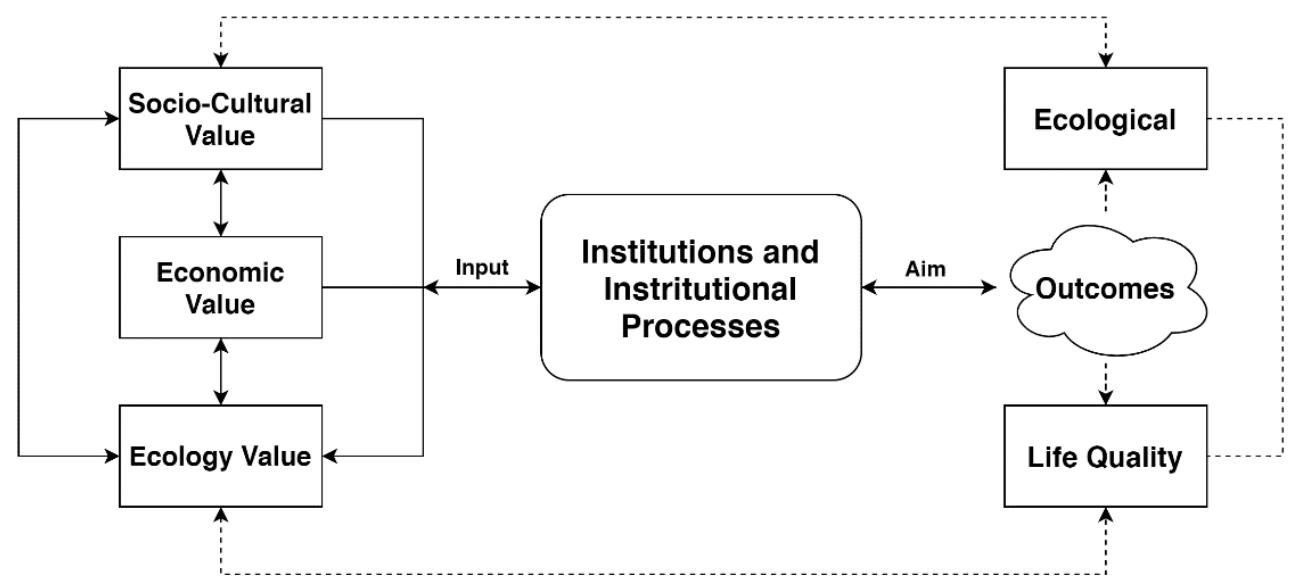

Fig. 1. The $\mathrm{CBC}$ concept on agricultural and coffee industry sustainability in Wonosobo is depicted in this mind map. There are three main sections: values, institutions, and institutional processes, and outcomes.

\subsection{Values from Agriculture and Coffee Industry in Wonosobo}

From the perspective of community-based conservation, three essential principles serve as the foundation for the sustainability of Wonosobo's agricultural and coffee industry. There is value in terms of socio-cultural, economic, and ecological.

\subsubsection{Socio-cultural value}

Since the people of Wonosobo have a tradition of drinking thick coffee, coffee consumption has continuously been rising (except in 2020) [2]. According to the informants, not only for the taste or the sensation while drinking, but people also love coffee as a medium to socially connect with other people. Furthermore, they regard coffee as a cultural value in and of itself.

When inviting others to gather in groups or individually, the word "yuk ngopi" ("let's have a coffee") is often used instead of more traditional phrases like "yuk nongkrong" ("let's hang out"). They believe something is lacking when they talk without drinking coffee. They also think coffee is better than other kinds of beverages.

\subsubsection{Economic value}

Wonosobo's high coffee consumption is also a manifestation of the rising economic importance of coffee. According to one senior farmer from Kapencar Village, the price of coffee beans was just IDR 1500-3000 per kilogram between 1998 and 2015. Farmers have been more aware of the potential of coffee since 2015. Then, they learned how to grow, care for, pick, and process coffee plants and beans. Nowadays, Coffee beans can cost up to IDR 10,000 per kilogram, depending on the farmer and distributor. They have suggested using an intercropping method to grow coffee without damaging or removing their original land (initially planted with vegetables). 


\subsubsection{Ecological value}

In Kapencar, massive coffee cultivation began in 1998. Farmers in Wonosobo were supported in the form of coffee crops as tall as $30 \mathrm{~cm}$ by the Central Java Provincial Government at the time. The original goal was to stop the erosion that was taking place at the moment. Then, farmers started to notice the advantages of coffee plants as erosion prevention after they were planted. Besides that, they believe that plating coffee could prevent land degradation at that time. Land degradation is defined as the loss of land capacity due to the land exceeding its ecological capacity [6]. It prevents plants from growing. They used to abuse the soil to plant tobacco, which resulted in the soil's quality deteriorating over time. When coffee is planted, the root function of the plantation can help to save more subterranean water and minerals for the soil.

Since recognizing the advantages of coffee plants in terms of erosion and land degradation reduction, the farmers learned about environmental techniques for improving and improving the production of coffee plants and beans. According to a coffee farmer and dealer, shade from other plantations or trees is necessary to prevent excessive sunlight exposure for the coffee plant. As a result, to preserve and increase the quality of their coffee plants, farmers are competing to grow trees. To ensure the freshness of the coffee beans, they also use organic and semi-organic farming methods.

\subsection{The Aim of CBC Implementation in Wonosobo's Sustainable Coffee Agriculture and Industry}

CBC seeks to improve, preserve, and utilize the values found and developed in Wonosobo's agriculture and coffee industry, as defined in 4.1: socio-cultural, economic, and ecological. The aim is set ought to be sustainable and mid to long-term.

\subsection{Institution and Institutional Processes}

In fulfilling the objective of CBC implementation for Wonosobo's Sustainable Coffee Agriculture and Industry, there are several roles involved with each of them.

Table 1. List of Involving Roles.

\begin{tabular}{|c|l|}
\hline No. & \multicolumn{1}{c|}{ Institutions } \\
\hline 1 & $\begin{array}{l}\text { Stakeholders } \\
\text { Central Java Provincial Government } \\
\text { Wonosobo Regional Government }\end{array}$ \\
\hline 2 & $\begin{array}{l}\text { The People } \\
\text { Residents of Wonosobo } \\
\text { Wonosobo coffee's consumer }\end{array}$ \\
\hline 3 & $\begin{array}{l}\text { The Farmer } \\
\text { Farmer as an individual } \\
\text { Farmers Group }\end{array}$ \\
\hline 4 & $\begin{array}{l}\text { Coffee Bean Processor } \\
\text { Coffee Bean Processors and Roasters } \\
\text { Coffee Shop / Café / Restaurant Business Owner }\end{array}$ \\
\hline
\end{tabular}




\subsubsection{Stakeholders}

In Wonosobo, the government is helping to fund coffee farmers and processors. As previously mentioned, the Provincial Government of Central Java provided farmers in Kapencar Village with assistance by donating coffee seeds in 1998. Then, in 2019-2020, the same assistance was provided to the village's Farmer Groups.

Aside from funding, stakeholders also assist farmers and coffee processors with education. From 1998 to 2015, coffee farmers in Kapencar Village relied on conventional planting, maintenance, harvesting, and post-harvesting methods. Following the high demand for coffee, stakeholders started to improve coffee farmers' capacity and ability.

Subsequently, the Wonosobo District Government has the empowerment and authority to develop, assess, and execute regional development plans. The government has identified robusta coffee and Wonosobo arabica as two possible community coffee management and plantation areas 76]. Not only can stakeholders impact economic value, but they also impact environmental factors under applicable policies.

The Wonosobo District Government and the Regional People's Representative Assembly cooperated in 2000-2001 to facilitate discussion and decision-making on Regional Regulation policies that govern community-based forest functions. The policy is regarded as a pro-people approach. This strategy will protect and preserve forests, but it can also maximize the potential of forest natural resources without fear of exploitation of forest products [8].

\subsubsection{The People and The Community Group}

Residents Residents in the region provide an essential role in the growth of coffee in Wonosobo. Planting coffee plants in their backyard gardens is one of the community's initiatives. The Dutch colonial government used a cultural method of forced cultivation (cultuurstelsel) to establish a coffee plantation and industry in Wonosobo, which was one of the critical commodities at the time. This scheme was identical to the paggerkoffij (kopi pager) system used in the Banyumas Residency [9]. The residents of Wonosobo are still used to the presence of coffee due to a long-standing coffee tradition. As a result, the coffee values in Wonosobo started to emerge and grow.

In terms of environmental factors in Wonosobo, the community also has a significant impact. Land degradation and exploitation are two of the sources of erosion that have occurred. Adi in Soeryo (2009) stated land depletion was calculated to be between 2300 and 5000 ha between 1998 and 2000 [9]. Starting in 2000, after the Wonosobo community became aware of the environmental degradation, and with the help of the Wonosobo District Government, the previously mentioned strategy of decentralization of forest management was established.

Without the movement of organizations, the community's power in caring for forest conditions in Wonosobo will not be recognized. At the time, NGOs, Farmer Associations, DPRD, Wonosobo District Government officials, and Perum Perhutani[1] were among the community organizations involved. The parties' discussions and collaboration ultimately culminated in a strategy known as Community-Based Forest Resource Management (PSDHBM), the contents of which were agreed upon by the majority of those involved. Then, A new policy called Community Forest Management (PHBM) was born after further debate and analysis [8]. Essentially, these policies give people the ability to preserve, maintain, and use trees and forest goods.

In conjunction with local wisdom, the existence of a community's collective awareness of the necessity of environmental protection is a form of the social modal. Communities with high social modal and background of community activities are more likely to participate in 
conservation initiatives and take collective action as a result. This type of active community engagement embodies community-based disaster governance techniques, in which social capital serves as the foundation for social interactions and connections in a community, as well as the most significant component in disaster communities' disaster governance ability [10].

As a result of these previously mentioned actions, the community now agrees that coffee quality and quantity are affected by environmental sustainability. If there is a lot of forest loss, the air temperature may rise. As a result, coffee varieties such as Arabica, which should be cultivated in colder climates, will struggle to thrive. People conserve the ecosystem in this manner in terms of ecological roles and from an economic point of view. Aside from the financial aspect, they are also aware that if no environmental conservation effort is taken in any form, they would be forced to deal with climate change, which may result in future natural disasters.

\subsubsection{The Farmer and Farmer Groups}

Farmers play an essential role in the sustainability of coffee farming and environmental conservation in Wonosobo since they employ most of the population. Initially, they were adamant about clearing land for vegetable and tobacco cultivation. Farmers started reducing major land expansion and taking preventative steps, including planting trees for reforestation and avoiding deforestation after forest degradation and erosion.

One of Kapencar's senior farmers agreed to stop tobacco cultivation and replace it with coffee plants. The farmer argued that tobacco plants degraded soil quality and that the entire process from planting to production was unfriendly to the community. Furthermore, he noted that coffee production must be supported by lush trees that can provide shade. Several farmers and farmer groups later imitated this practice.

Aside from environmental initiatives, farmers strive to increase the quality and quantity of Wonosobo coffee production in other ways. They practice planting, treatment, harvesting, and post-harvest processing techniques in an eco-friendly manner. For, e.g., they left the full stumping process to the pruning method. The aim is to balance vegetative and generative plants to increase productivity and make pest and insect management easier without dangerous chemicals. Since pruning, the remaining leaves are used as animal feed, and the manure is used as fertilizer. Meanwhile, the timber is used as firewood. They harvest using the red picking process to obtain the best coffee beans based on the desired flavor. This system is often used to avoid wasting young coffee beans.

\subsubsection{Coffee Beans Processors and Distributors}

Farmers who are both processors and distributors use eco-sustainable practices as well. Each farmer has his or her process. There are natural, full-wash, semi-wash, probiotic, wine, and other varieties, each with its distinct flavor. Regardless of the method, unused coffee hulls are processed into cascara ${ }^{2}$ by several coffee producers.

Farmers who do not process and sell their coffee beans take the services of third parties. On the other hand, these groups have high expectations regarding buying coffee beans from farmers. By this, they attempt to increase their coffee beans' consistency to meet this demand. Due to the demand, experienced coffee processors and farmers provide education and instruction on growing, caring for, and harvesting coffee beans according to demand to help alleviate shortages. As a result, Wonosobo coffee goods, which are sold as household needs

\footnotetext{
${ }^{2}$ Coffee cherry tea
} 
and in coffee shops or cafés, use only the finest beans. The quality and quantity of Wonosobo coffee may be preserved and even increased as a result of this.

\subsection{Established and Desired Outcomes}

After implementing CBC, both collectively and instinctively, all informants agreed that what has been done so far in Wonosobo's coffee agriculture and industry practice has improved community and environmental quality of life. With interpersonal synergies and strong connections between humans and the environment, existing values may be both potential and beneficial.

On socio-cultural value, the higher the quality and quantity of agricultural production and coffee industry in Wonosobo, the interaction between people would rise in quality and quantity when they gather and enjoy coffee whether as a part of their culture or needs. Economically, people can enhance their welfare. As people's welfare increases, the quality of living and spending capacity will also grow. Finally, in terms of ecological value, with the deployment of the $\mathrm{CBC}$ system, the practice of natural resource conservation will be substantially realized. By improving environmental consciousness, the degree of environmental damage purposely done for human benefit will decrease.

If the $\mathrm{CBC}$ system is continually applied and evaluated regularly at both community and inter-elemental levels of coordination, the values that come from coffee and its environment will be both input and outcome for creating additional programs. By creating sustainability, individuals can overcome any problems better, even in the Covid-19 pandemic situation.

\section{Conclusion}

Agriculture and the coffee industry in Wonosobo have potential socio-cultural, economic, and ecological values. When the $\mathrm{CBC}$ practice is used as a framework for achieving sustainability, all stakeholders, including policymakers, governments, producers, and coffee entrepreneurs, collaborate to accomplish and feel the desired outcomes. They aim to utilize synergy between nature and industry to increase their life and environmental quality. As part of an ecosystem, CBC helps ensure that the community will flourish while simultaneously maintaining, sustaining, and using the environment. If this is carried out in the future, it will establish a level of sustainability that will enable it to flourish even in a pandemic situation.

\section{Acknowledgment}

The writer would like to express his heartfelt gratitude to the Dean of the Humanities Faculty at Diponegoro University for providing this chance to participate in and fund this research.

\section{References}

1. BPS Wonosobo. Kabupaten wonosobo dalam angka 2020. BPS Wonosobo https://wonosobokab.bps.go.id/publication/2020/04/27/41af71106bf0d65990173f63/kab upaten-wonosobo-dalam-angka-2020.html (2020)

2. S. Dinda, E. Fitriani. Konsumsi kopi di Indonesia naik $44 \%$. https://investor.id/business/konsumsi-kopi-di-indonesia-naik-44. Investor.id (2020)

3. Dispaperkan Wonosobo. Data komoditas perkebunan Kabupaten Wonosobo tahun 2019. https://dispaperkan.wonosobokab.go.id/data-komoditas-perkebunan-kabupatenwonosobo-tahun-2019/. Wonosobokab.go.id (2019) 
4. W. Wiryono. Pengantar Ilmu Lingkungan. (2013)

5. W. Adams and D. Hulme, "If Community Conservation Is the Answer in Africa, What Is the Question?," Oryx 35(3), 193-200, https://doi.org/10.1046/j.13653008.2001.00183.x.

6. Khormali, F., et al. "Role of deforestation and hillslope position on soil quality attributes of loess-derived soils in Golestan province, Iran." Agriculture, ecosystems \& environment 134.3-4 (2009): 178-189.

7. Bappeda Wonosobo. Rencana pembangunan jangka menengah daerah Kabupaten Wonosobo tahun 2016-2021. http://data.jatengprov.go.id/dataset/rpjmd-wonosobotahun-2016-2021. Open Data Provinsi Jawa Tengah (2016)

8. S. Adiwibowo, R. Mardiana. Pengelolaan Kolaboratif Hutan Produksi Berbasis Masyarakat: Kasus Pengelolaan Hutan Negara di Wonosobo, Jawa Tengah. Social Forestry di Indonesia: Kolaborasi Pengelolaan Sumberdaya Hutan, 107-160 Departemen Kehutanan (2009)

9. M. Yuan. Perkebunan Kopi di Karesidenan Banyumas Masa Tanam Paksa Tahun 1836-1849. Jurnal Ilmu Sejarah-S1, 3(7). (2018)

10. Nakagawa \& Shaw, Social Capital:A Missing Link to Disaster Recovery, International Journal of Mass Emergencies and Disasters March 2004, Vol. 22, No. 1, pp. 5-34 